Munzir Hitami, Studi Islam Pada Program...

\title{
STUDI ISLAM PADA PROGRAM PASCASARJANA UIN SULTAN SYARIF KASIM RIAU
}

\section{Munzir Hitami}

Abstrak: Dalam suasana perkembangan ilmu pengetahuan dan teknologi dewasa ini, studi agama khususnya studi Islam juga mengalami perkembangan sekaligus tantangan. Tantangan terutama muncul dari berbagai cabang ilmu pengetahuan baru yang digunakan sebagai alat dan pendekatan terhadap studi agama. Pada satu sisi, studi agama (Islam) bertujuan memperkuat dan mempertahankan kepercayaan terhadap agama itu, namun pada sisi lain studi agama sebagai studi akademis mengehendaki segala objeknya didudukkan pada tempat yang sama, yang dapat dianalisis, dinilai, dan dikritik. Hal ini berarti mungkin akan merusak kepercayaan terhadap agama itu sendiri. Dalam pergulatan studi agama yang menjadi lapangan utama kajian pada Program Pascasarjana IAIN atau UIN, setidaknya ada beberapa pendekatan yang digunakan, yakni pendekatan dogmatik, ekelektik, ilmiah, dan post-modernism. Program Pascasarjana akan dibawa kemana. Terlepas dari pergulatan itu Program Pascasarjana UIN Suska ingin mengembangkan studi area Islam Asia Tenggara sebagai bidang utama yang dikembangkan dan menjadi center of exellence.

Kata-kata Kunci: Studi Islam, studi area, dan pendekatan (approach).

Abstract: In the circumstance of scientific development nowadays, the religious study, especially Islamic study, also undergoes development and threat as well. The threat mainly rises from new different branches of sciences that are used as tools and approaches toward religious study. On the one hand, the religious study like Islamic study is usually intended to strengthen and defend the religious belief, and on the other hand, the religious study as academic subject demands all its objects to be placed in 
Munzir Hitami, Studi Islam Pada Program...

the equal positions in which enable it to analyze, assess, and criticize itself. This means that the study may damage such religious belief. In the wrestling of religious study that becomes main subject of study in the Graduate Program of IAIN or UIN, there are several approaches used in religious study, namely: dogmatic, eclectic, scientific, and post-modernist approaches. Apart from such wrestling, the Graduate Program of UIN SUSKA wants to develop area study of Southeast Asian Islam as core subject and center of excellence of studies in the program.

Key words: Islamic studies, area study, and approach.

$$
\begin{aligned}
& \text { الملخص: فن مناخ تطور العلوم و التكنولوجيا اليوم الدراسات الدينية وبالخاص الدراسات الإسلامية } \\
& \text { تتطور مثله كما هى تواجه أيضا التحديات. و هذه التحديات لاسيما تصدر من مختلف فروع العلوم } \\
& \text { الجديدة التى تستعمل كالأدوات و نقطة الاقتراب إلى تلك الدراسات. و إن الدرسات الدينية } \\
& \text { الإسلامية تقصد من ناحية إلى تقوية الإيمان و مدافعته، و من ناحية أخرى فإنها كالدراسات }
\end{aligned}
$$

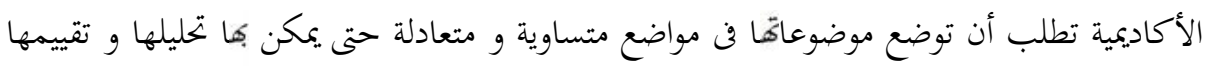

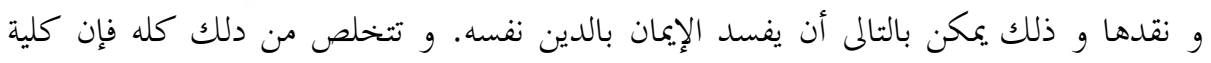

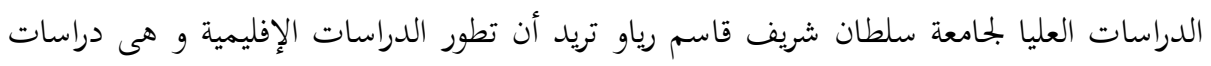

$$
\begin{aligned}
& \text { جنوب شرق آسيا الإسلامية كالمواد الأساسية و تكون كالمركز الامتيازى لها }
\end{aligned}
$$

Ketika ilmu pengetahuan dengan segala perangkatnya berkembang, dan dengan demikian sarana studi dan pisau analisis bertambah kaya, maka studi agama menghadapi berbagai tantangan dalam menumbuhkan pendekatan-pendekatan terhadapnya. Tantangan tersebut bersumber dari sebuah konsep yang sering menjadi postulat bagi studi ilmiah bahwa sebuah studi ilmiah mensyaratkan seseorang untuk bersikap ilmiah, yakni: mengambil jarak terhadap objek studi, bersikap imbang, kritis dan terbuka terhadap segala kemungkinan penilaian. Hanya dengan itu 
Munzir Hitami, Studi Islam Pada Program...

seseorang mampu melihat objek studinya secara lebih terbuka, di mana temuan-temuannya siap diperiksa ulang oleh orang lain melalui suatu prosedur tertentu. ${ }^{\mathrm{i}}$

Dalam sejarah perkembangan studi akademik terhadap agama-agama termasuk Islam, studi tersebut telah dipenuhi oleh berbagai wacana dan perdebatan. Hal itu terjadi karena hasil studi tersebut tidak jarang menimbulkan kesenjangan (gap) dengan apa yang selama ini dipercaya oleh umat-umat beragama, karena pada akhirnya sampai kepada klaim akan kebenaran agama tertentu dan menolak atau menganggap salah agama lain, atau paling tidak agamanya superior terhadap agama lain.

Hasil studi yang dilakukan oleh pihak luar agama bersangkutan sering dicurigai sebagai tuduhan dan serangan terhadap agamanya, sebagaimana halnya yang terjadi pada kaum orientalis ketika mereka melakukan studi terhadap Islam yang sering membandingkannya dengan Kristen ataupun Yahudi. Kecurigaan ini bersumber dari hal-hal yang bersifat teologis di sepanjang sejarah Islam sendiri karena Islam muncul dalam suasana dan lingkungan Judio-Christian yang langsung berhadapan dengan agama yang sudah ada sebelum agama Islam tersebut. Persaingan antar agama-agama tersebut mulai pada masa awal Islam sampai pada perang salib, dan masa moderen sekarang ini, telah memperkuat sikap curiga tersebut. Hal ini juga diperkuat oleh interpretasi terhadap ayat al-Quran al-Baqarah, 120.

Pada zaman modern muncul kegiatan studi Islam yang lebih luas dari bangsa Eropa atau Amerika yang melahirkan ahli-ahli tentang Timur atau yang biasa disebut Orientalis tersebut. Studi mereka ini tidak terlepas dari berbagai kepentingan seperti kepentingan missionaris Kristen dan politik penjajahan. Keberadaan orientalis dari kalangan pendeta dan misionaris menyuburkan kecurigaan bagi umat Islam yang ujung-ujungnya 
Munzir Hitami, Studi Islam Pada Program...

adalah terbentuknya sebuah imej untuk "menghancurkan Islam". Bukti ketidakmurnian studi orientalis terhadap Islam demi kepentingan politik penjajahan mereka, disebutkan oleh Edward Said:

"My idea is that European and then American interest in the Orient was political according to some of the obvious historical accounts of that I have given here, but that it was the cultural that created that interest, that acted dynamically along with brute political, economic, and military rationales to make the Orient the varied and complicated place that it obviously was in the field I call Orientalism." ii

\section{Problem Pendekatan}

Terlepas dari segala prejudice yang melekat pada studi agama tersebut baik yang dilakukan oleh sarjana non-Muslim seperti Orientalis, maupun yang dilakukan oleh sarjana Muslim sendiri, makalah ini mencoba untuk melihatnya jika diandaikan dilakukan murni dengan melihat realitas yang ada. Setidaknya ada empat pendekatan yang berkembang dalam melakukan studi yang objeknya agama: pendekatan dogmatis, pendekatan eklektik, pendekatan secular dikotomik, dan pendekatan fenomenologis/post-modernism.

\section{a. Pendekatan Dogmatis}

Pendekatan ini yang biasa digunakan oleh umat beragama untuk mempelajari agamanya. Agama dipelajari dengan dasar keimanan dan untuk memperkuat iman. Ajaran agama ditempatkan pada posisi sacral atau suci yang kebal terhadap kritik, karena agama merupakan ajaran yang bebas dari kesalahan (inerrant). Tujuan mem-pelajari agama adalah untuk memahami dan menghayati ajaran agama bersangkutan agar iman bertambah 
Munzir Hitami, Studi Islam Pada Program...

kuat dan dapat membimbing praktek dan tingkah laku sehari-hari serta untuk keperluan pelaksanaan upacara-upacara ritual atau ibadah.

Pendekatan ini tidak menggunakan rasio dan apalagi pendekatan ilmiah. Hal ini didasarkan pada kenyataan bahwa agama memang untuk dipercaya dan diimani serta diamalkan, bukan untuk dinilai, diukur, atau apalagi dikritik. Ajaran agama bukanlah objek studi melainkan sebagai salah satu subjek studi atau disiplin pengetahuan yang wajib dipelajari sebagai penuntun manusia dalam kehidupan. Pendekatan ini biasanya menghasilkan sikap eksklusivisme dan absolutisme agama. Agama yang benar adalah satu, yaitu agama yang dianutnya.

\section{b. Pendekatan Eklektik}

Pendekatan ini merupakan pendekatan konvergensi antara pendekatan dogmatis dan pendekatan rasional. Pendekatan ini berupaya memahami dan mempalajari agama secara rasional sambil tetap mempertahankan ke-imanannya kepada agama yang dianut sendiri. Pendekatan ini muncul sebagai reaksi dari tuntutan zaman ketika berkembangnya filsafat yang banyak menghujat kepercayaan agama. Berawal untuk kepentingan pembelaan kepada agama (apologi) dari serbuan filsafat pada abad pertengahan di mana agama dipelajari dengan pendekatan rasional sehingga dapat menjawab kritik atau keberatan filsafat terhadap agama.

Dari sini dikenal kelompok filosof muslim dalam sejarah Islam pada abad pertengahan. Pada zaman modern kelompok ini mendapat "energi" kembali dengan munculnya tokoh-tokoh reformasi Islam dari kalangan Modernis di India seperti Iqbal, Amir Ali, Ahmad Khan sebagai perintis kaum rasional yang mempelajari agama dengan pendekatan eklektik ini. Pada zaman sekarang ini muncul pula kelompok intelektual seperti Hassan Hanafi, Muhamad Imarah, Muhammad Arkoun, Nasir Hamid 
Munzir Hitami, Studi Islam Pada Program...

Abu Zaid dan lain-lainnya, dan di Indonesia muncul pula kelompok yang menamakan diri dengan kelompok liberal atau pemikiran Islam liberal.

Kelompok ini pada hakikatnya melakukan studi agama dengan pendekatan eklektik ini untuk membela dan mempertahankan agama dengan memberikan pemahaman agama yang sesuai dengan perkembangan zaman sekarang, sehingga ajaran agama nampak moderen dan sesuai dengan zaman.

Pendekatan ini biasanya menghasilkan sikap inklusivisme, yakni sikap menerima adanya kemungkinan kebenaran agama luar tercakup dalam kebenaran agamanya (inclusive) karena keluasan dan keluwesan ajaran agama tersebut.

\section{c. Pendekatan Sekular Dikotomis}

Pendekatan ini didasarkan pada asumsi bahwa dalam studi agama, pendekatan dogmatis dan pendekatan ilmiah tidak dapat disatukan atau digabung. Keduanya ibarat air dengan minyak. Menerima yang satu berarti menolak yang lain. Hal itu karena adanya asumsi-asumsi dasar yang saling kontradiksi antara keduanya. Pendekatan ilmiah mengehendaki semua objek garapannya sama rata dan tidak "pandang bulu". Objek kajian ilmiah tidak boleh ada yang tabu dan sakral yang kebal kritik, sementara pendekatan dogmatis ada batas-batas yang tegas yang tidak boleh dikritik. Mental pendekatan dogmatis kaku dan tidak berubah, sementara pendekatan ilmiah lentur dan bersifat kritikal.

Kekakuan tersebut sebenarnya wajar karena mental dogmatis sudah terbentuk sejak manusia masih kecil sampai dewasa. Kekakuan mental (La rigidite mentale), adalah ketidakmampuan seseorang mengubah perangkat pikiran atau mentalnya ketika dituntut persyaratan objektivitas, termasuk ketidak-sanggupannya menyediakan kerangka atau ruangan yang berisi multi-alternatif bagi pemecahan satu masalah agar masalah 
Munzir Hitami, Studi Islam Pada Program...

itu dapat dipecahkan dengan seefektif-efektifnya. ${ }^{\text {ii }}$ Dalam hal ini ada macam spirit (ruh), yakni spirit terbuka dan spirit tertutup berikut struktur bangunan masing-masing serta keterkaitan yang terakhir itu dengan mental dogmatisme dengan menekankan tingkat keterkaitan mental dogmatisme dengan system ideology tertentu.

Rokeach menggunakan istilah "Sistem aqidah" (Systeme de croyances) dan memandang mental dogmatis berpusat pada dikotomis ekstrim antara system iman atau aqidah dengan sisten non-iman atau non-aqidah. Dengan kata lain, bahwa mental dogmatis berkaitan dengan keketatannya yang kuat berpegang kepada seperangkat prinsip aqidah, dan menolak dengan keras perangkat lain yang di luarnya dan dianggap tidak berarti atau tidak berguna. Karena itu prinsip-prinsip aqidah itu merupakan kawasan terlarang bagi pemikiran rasional, atau bahkan mustahil dirasionalkan.

Bila dipinjam istilah Rokeach ini, maka system iman dan non-iman tersebut dapat dibatasi pada hal-hal berikut: 1) merupakan gambaran dari suatu pengetahuan tertutup yang terbentuk dan berporos pada problem aqidah dan non-aqidah (Keyakinan penuh atau bukan keyakinan), 2) merupakan sesuatu yang berporos pada poros keyakinan penuh yang mempunyai kekhususan sendiri dan mutlak, 3) bahwa hal tersebut melahirkan serangkaian masalah toleransi atau intoleransi terhadap pihak lain. ${ }^{\text {iv }}$

Kemudian tingkat dogmatisme pandangan manusia dapat diukur dengan beberapa hal, antara lain:

1) Suatu struktur atau system pengetahuan tertentu menjadi dogmatis sejauh adanya tembok tebal yang membatasi antara system iman dan aqidah dengan system non-iman yang khusus baginya (Le belief-system/et les dis-belief-systems). Ada paling tidak empat cara bagi terwujudnya hal tersebut: 
Munzir Hitami, Studi Islam Pada Program...

memperkuat strategi di atas perbedaan-perbedaan yang ada antara system iman dan system non iman, b) pemapanan atas kondisi di mana tidak dibenarkan penghujatan-penghujatan yang dapat mencampur adukkan antara keduanya, c) menolak dengan keras kemudian meremehkan segala realitas yang kadang-kadang muncul bertentangan dengan aqidah tersebut, dan d) kemampuan untuk menerima berbagai kontradiksi di dalam system iman atau aqidah itu tanpa merasa adanya masalah apapun.

2) Suatu konstruksi pengetahuan dogmatis selalu memperlebar jurang pemisah antara kedua system yang bertentangan tersebut (dikotomi murni), yang tercermin pada upaya-upaya: a) penolakan terus menerus setiap upaya pendamaian atau penyelarasan di antara kedua system, b) keyakinan terus menerus dan bertambah-tambah terhadap pengetahuan hakiki yang hanya dimiliki pihaknya, dan c) kemudian keyakinan yang kuat terhadap kebatilan system yang ada di luarnya.

3) Suatu konstruksi pengetahuan dogmatis menyama-ratakan segala system yang ditolaknya (pokoknya semuanya itu salah), yang benar hanya satu.

4) Suatu konstruksi pengetahuan dogmatis bila keyakinankeyakinan pinggiran mesti bergantung kepada keyakinan sentral yang mendasar. Segala sesuatu yang pinggiran mesti diacukan dan disesuaikan dengan sentralnya dengan berbagai rasionalisasi atau justifikasi, sehingga seolah-olah tidak ada masalah dan terlihat kehebatan keyakinan sentralnya.

5) Suatu struktur pengetahuan dogmatis bila perspektif dan visi kontemporernya selalu diarahkan kepada marcusuar masa lalu, yakni masa sekarang sangat tergantung kepada masa keemasan murni (konsep utopia). ${ }^{\mathrm{v}}$ 
Munzir Hitami, Studi Islam Pada Program...

Kesemua sifat dan karakteristik pengetahuan dogmatis sangat berbeda dan bertentangan dengan pengetahuan ilmiah, sehingga pendekatan ilmiah dan pendekatan dogmatis tidak dapat disatukan secara mendasar dalam studi agama. Pendekatan ini akan menghasilkan dan bertitik tolak dari asumsi dasar yang memandang agama sebagai semata gejala kemanusiaan (human phenomenon) yang terekspresi dalam kehidupannya baik secara individual, maupun sosial.

\section{d. Pendekatan Fenomenologi}

Pendekatan fenomenologi ini pada zaman sekarang diwakili oleh kelompok post-modernisme. Kelompok ini bertitik tolak pada asumsi dasar tentang kegagalan gerakan modern untuk memberikan makna bagi kehidupan manusia karena manusia direduksi hanya sebagai gumpalan tulang dan daging yang berfikir. Pandangan hidup sains modern telah gagal menuntun manusia ke arah yang lebih cerah. Dimensi relijius dalam kehidupan manusia telah dilupakan oleh kaum modern, sebagaimana halnya nilai-nilai normative yang dianut masyarakat.

Post-modernisme memandang setiap agama pada tingkatan yang sama-sama benar, karena tidak ada kebenaran yang mutlak. Kebenaran bukanlah sesuatu yang asimetris, melainkan sesuatu yang simetris yang mana antara satu dengan yang lainnya tidak dapat melakukan gerakan silang untuk memaksakan kepercayaan kepada yang lainnya, dan karena itu tidak dapat saling mengklaim akan kebenarannya sendiri. Agama setara dengan seni, dan bahkan seni dapat menggantikan agama. Keduanya merupakan pintu gerbang untuk masuk kepada pengalaman yang real, yaitu kehidupan yang otentik dan bukan jalan untuk keluar daripadanya. Agama masa depan akan menjadi agama pengalaman penuh. Kebenaran ibarat jasmaniah (carnal), dan Energi yang berasal dari jasadnya merupakan makna kata yang 
Munzir Hitami, Studi Islam Pada Program...

benar yang membentuk daging. ${ }^{v i}$ Hal itu dapat dihayati dan dialami dalam kancah pengalaman emosional dan spiritual. Kebenarannya pada diri seseorang yang mengalaminya tak dapat disangkal dan dibatalkan oleh siapapun.

Meskipun gerakan ini merupakan gerakan yang kabur, di antara tokoh kelompok ini yang dapat diidentifikasi antara lain Geoffrey Hartmann dan Fritjof Capra. Pendekatan ini biasanya akan menimbulkan sikap pluralisme dalam memandang agama.

\section{III}

\section{Pendekatan Studi Islam: Tantangan Ke Depan}

Pendekatan-pendekatan sebagaimana yang telah dikemukakan terdahulu tentu saja mempunyai kelebihan dan kekurangan, dan lebih dari itu menimbulkan diskusi dan perdebatan yang cukup tajam. Pendekatan dogmatis selama ini sudah cukup mengakar dan mapan dalam belajar agama, bukan saja di kalangan awam, tetapi juga pada tingkat pendidikan tinggi terutama pada kelompok-kelompok ortodoksi Muslim dan bahkan juga di kalangan UIN, IAIN, dan STAIN. Ketika gagasan pembaharuan Harun Nasution diterapkan pada studi agama, maka mulailah terjadi perubahan arah dan orientasi pendekatan. Ide-ide pendekatan eklektik mulai mendapat tempat. Sebagai akibatnya, dari beberapa kelompok Muslim di Indonesia, UIN, IAIN, dan STAIN dituduh sebagai pusat "itizalisasi" (penyebaran paham mu'tazilah). Ditinjau dari sudut pandang akademis pendekatan eklektik memang nampaknya menarik. Namun pendekatan ini tidak dapat mengatasi paradoks internal yang terdapat di dalamnya sebagaimana keberatan yang diajukan oleh pendekatan dikotomi, dan bahkan sering terkesan sebagai 
Munzir Hitami, Studi Islam Pada Program...

pendekatan apologetik. Begitupun pendekatan fenomenologi post-modernism mendapat tantangan dari dunia muslim sendiri.

Pengembangan studi agama di UIN, IAIN atau STAIN mendapat tantangan dalam memilih pendekatannya. Sebagai perguruan tinggi, UIN, IAIN dan STAIN mengemban misi akademis yang mengharuskan agama diletakkan sebagai objek kajian yang setara dengan objek-objek kajian lainnya, dan dipihak lain ia juga mengamban misi agama itu sendiri, sebagai lembaga dakwah yang bertujuan memperkuat agama atau iman dan ketaqwaan kepada Allah SWT yang keduanya saling berlawanan. Arkoun mengajukan pertanyaan, apabila seorang akademisi atau ilmuwan dihadapkan kepada pilihan yang bertentangan tersebut. Apakah sepatutnya digunakan pendekatan studi Islam itu bersandar kepada konsep Islam dengan pengertiannya yang transenden karena ia satu-satunya ajaran sunnah atau turâts ideal yang merepresentasikan "kebenaran" yang diterima oleh umat yang ideal pula? Ataukah studi Islam didekati dengan sebuah upaya re-definisi Islam menurut sifatnya sebagai sebuah proses social dan historis dari sejumlah proses dan jalur lain di mana ia telah bergeser dan berubah melalui berbagai kreasi yang terus menerus?vii

Kedua misi tersebut (misi agama dan misi akademis) merupakan dua hal yang sudah membuat UIN, IAIN dan STAIN berada di persimpangan jalan, yang mungkin jadi di masa depan berkembang ke arah perdebatan yang sengit sehingga melemahkan salah satu misi tersebut sebagaimana yang dialami oleh bangsa Eropa pada akhir-akhir abad pertengahan dan ada akhirnya meruntuhkan agama. Apalagi dalam kondisi perkembangan teknologi komunikasi sekarang ini yang membuka seluas-luasnya berbagai tawaran cara pandang dan budaya dalam kehidupan ini. Hal tersebut jelas akan menimbulkan keguncangankeguncangan (shock) dalam kehidupan manusia. Di sini Perguruan tinggi seperti UIN, IAIN atau STAIN akan berperan seperti apa? Misi agama yang diembannya akan mengalami nasib seperti apa? Di sini secara ideal 
Munzir Hitami, Studi Islam Pada Program...

dituntut adanya suatu peran yang bermain sebagai penyelaras, namun bagaimana hal itu dilakukan?

\section{IV}

\section{Pilihan-pilihan}

Program Pascasarjana UIN Sultan Syarif Kasim Riau memiliki lima konsenstrasi, yaitu: Perkembangan Islam Regional Asia Tenggara (PIRAT), Perkembangan Modern Dalam Islam (PMDI), Hukum Islam (HI), Pendidikan Islam (PI), dan Managemen Pendidikan Islam (MPI). Kelima konsenstrasi tersebut mempunyai basis studi Islam sebagai matakuliah pokok.

Menyikapi masalah pendekatan dan metodologi sebagaimana tersebut dahulu, Program Pascasarjana UIN Sultan Syarif Kasim Riau cenderung untuk mengembangkan upayaupaya: Pertama, pembentukan "kedewasaan berpikir" dengan memberikan wawasan seluas mungkin bagi para mahasiswa mengenai perkembangan pendekatan dan metodologi studi agama. Kedua, untuk mengimbangi perdebatan tentang pendekatakan studi agama, maka dimunculkan kecenderungan lain dari bentuk konvensional studi agama yang ada, yakni area studies ditandai dengan pembentukan studi 'Perkembangan Islam Regional Asia Tenggara' yang diharapkan menjadi center of excellence pada Program Pascasarjana UIN Susltan Syarif Kasim Riau. Pada masa depan direncanakan pula untuk membuka studi Perkembangan Islam Asia Timur dan Perkembangan Islam Asia.

Sebagaimana dimaklumi bahwa konsep dasar dari area studies adalah bahwa manusia yang menempati sebuah sector geografis tertentu yang berperilaku dalam masyarakat dan lingkungan mereka menawarkan sebuah unit yang laik untuk

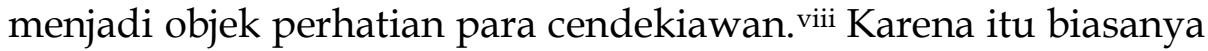
studi area menggunakan pendekatan inter-disiplin terhadap agama, yakni studi tentang pola tingkah laku individu atau sosial 
Munzir Hitami, Studi Islam Pada Program...

dan budaya suatu kawasan yang bersumber dari ajaran agama, dan bukan studi tentang ajaran agama itu sendiri.

Studi area sebenarnya bukanlah hal yang baru karena ia sudah ada sejak zaman kuno. Namun perkembangan yang berarti terjadi setelah perang dunia II yang banyak menyisakan sumberdaya spesialis yang ahli dan terlatih pada bidang bahasa, budaya, dan karakteristik topografikal berbagai area di dunia di mana para serdadu harus bertempur dan juga keputusankeputusan social politis harus dibuat. Di Amerika serikat selama perang banyak tenaga dilatih pada program-program bahasa tertentu yang diselenggarakan oleh angkatan bersenjata. Programprogram ini memberikan pembelajaran intensif mengenai bahasa Jepang, Cina, dan bahasa-bahasa lainnya di dunia. Kemudian perang dingin antara Barat dan Timur mendorong munculnya studi-studi yang berkaitan dengan area "musuh". Demikianlah dengan bantuan dana dari Carnagie Corporation of New York dan Rockefeller Foundation, Universitas Columbia dan Harvard mendirikan pusat studi Rusia. Organisasi dari pusat-pusat studi ini beserta hasil-hasilnya telah memberikan model bagi berbagai studi area lainnya. ${ }^{\text {ix }}$

Di Inggeris, lembaga seperti School for Oriental and African Studies yang telah berdiri sejak tahun 1916 dalam program latihan bahasa untuk kepentingan kolonial, telah mengalami perkembangan yang pesat sejak tahun 1945 sehingga mencakup studi-studi sosial dan budaya. Sejak zaman itu sampai sekarang, studi area sudah merupakan institusi akademis yang cukup mapan dan diakui. Hal-hal tersebut dikemukakan tidak lain untuk memberikan landasan pijak, kenapa studi area dipilih untuk dikembangkan. Tambahan lagi, studi area memang masih langka di lingkungan IAIN.

Selain itu, studi area mempunyai konotasi sebagai programprogram training dan penelitian yang bersifat inter-disiplin bagi 
Munzir Hitami, Studi Islam Pada Program...

bagian-bagian tertentu dunia ini, yang mungkin jadi sebuah negeri atau sekelompok negeri semacam area Asia Tenggara. Pembukaan studi area di UIN Sultan Syarif Kasim Riau bukan tidak mengalami kendala. Kendala utama adalah sumber daya yang ahli dan terlatih terutama pada bidang bahasa tempatan dan tenaga ahli inter-disipliner lainnya. Pemilihan Asia Tenggara adalah dengan pertimbangan bahwa mayoritas masyarakatnya paham bahasa Melayu. Namun demikian, tenaga-tenaga yang ahli dalam bahasa tempatan seperti bahasa Tagalog (Moro), Karen (Myanmar), Bugis, Jawa, dan lainnya tetap diupayakan.

Meskipun pada awalnya studi area sarat dengan kepentingan dan ideologi tertentu, maka dewasa ini tugas para ilmuwan adalah membersihkan program-program yang dilaksanakan dari segala kepentingan yang tidak layak atau relevan dengan kepentingan akademis. Kepentingan yang relevan dengan zaman sekarang untuk meningkatkan kesejahteraan masyarakat, menegakkan perdamaian, menumbuhkan saling pengertian dan toleransi.

\section{DAFTAR PUSTAKA}

Arkoun, Muhammed. 1987. Al-Fikr al-Islâmî: Qirấah 'Ilmiyah, Terj. Hasyim Saleh. Beirut: Mrkaz al-Inhâ' al-Qawmî.

Deconchy, Jean Pierre. 1970. "Milton Rokeach et la notion de dogmatisme", Archieves de Sociologie des Religions, 30, 1970.

Falck, Colin. 1989. Myth, Truth, and Literature: Towards a True PostModernism. Cambridge: Cambridge University Press.

Komaruddin Hidayat dan Hendro Prasetyo (Ed.) 2000. “Menilik Dinamika IAIN: Sebuah Pengantar", dalam Problem dan Prospek IAIN: Antologi Pendidikan Islam. Jakarta: Ditbinperta Islam.

Said, Edward W. 1979. Orientalism, (New York: Vintage Books. 
Munzir Hitami, Studi Islam Pada Program...

Sills, David L. (Ed.) International Ecyclopedia of the Social Sciences. I. New York: The Macmillan Company \& the Free Press.

Tracy, David. 1987. Plurality and Ambiguity: Hermeneutics, Religion, Hope. San Francisco: Harper \& Row.

i Lihat:Komaruddin Hidayat dan Hendro Prasetyo, (Ed.) "Menilik Dinamika IAIN: Sebuah Pengantar", dalam Problem dan Prospek IAIN: Antologi Pendidikan Islam, (Jakarta: Ditbinperta Islam, 2000), xii.

ii Edward W. Said, Orientalism, (New York: Vintage Books, 1979), 12.

iii Lihat: Jean PierreDeconchy, "Milton Rokeach et la notion de dogmatisme", Archieves de Sociologie des Religions, 30, 1970, 6

iv Ibid.

v Ibid.

vi Lihat: Colin Falck, Myth, Truth, and Literature: Towards a True PostModernism, (Cambridge: Cambridge University Press, 1989), 170.

vii Muhammed Arkoun, Al-Fikr al-Islâmî: Qirâ'ah 'Ilmiyah, Terj. Hasyim Saleh, (Beirut: Mrkaz al-Inhâ' al-Qawmî, 1987), hal. 19.

viii Lihat: Bryce Wood, "Area Studies" dalam David L. Sills (Ed.), International Ecyclopedia of the Social Sciences, I, (New York: The Macmillan Company \& the Free Press, ), 401-7.

ix Lihat: Ibid. 